\title{
Phosphorus bioavailability in soybean grown after pasture under different fertility regimes
}

\section{Biodisponibilidade de fósforo em soja cultivada em sucessão à pastagem sob diferentes níveis de fertilidade}

\author{
Diogo Néia Eberhardt'; Thierry Becquer²; Robélio Leandro Marchão ${ }^{3}$; \\ Pedro Rodolfo Siqueira Vendrame ${ }^{4}$; Lourival Vilela ${ }^{3}$; \\ Edemar Joaquim Corazza ${ }^{5}$; Maria de Fátima Guimarães ${ }^{6 *}$
}

\begin{abstract}
The aim of this study was to evaluate the residual effect of phosphorus (P) fertilizer applied to an Urochloa decumbens $\mathrm{cv}$. Basilisk pasture on the P bioavailability to the following soybean crop. Lowproductivity pasture, planted on an Oxisol in an experimental field at Embrapa Cerrados, was divided into three strips, each of $1.5 \mathrm{ha}$ and fertilized by broadcasting annual applications of 0,20 and $40 \mathrm{~kg}$ ha $^{-1}$ of $\mathrm{P}_{2} \mathrm{O}_{5}$ for four years. After the pasture was desiccated with herbicide, soybeans were sown and fertilized with 0,50 and $100 \mathrm{~kg} \mathrm{ha}^{-1}$ of $\mathrm{P}_{2} \mathrm{O}_{5}$ applied within each strip, making a total of nine $(3 \times 3) \mathrm{P}$ treatments. Residual available P content (Mehlich-1 and resin) from the pasture fertilization was lower than from soybean fertilization. However, the bioavailable residual $\mathrm{P}$ from the pasture, determined by $\mathrm{P}$ accumulated in plants, production of dry matter and grain yield, had similar availability to inorganic $\mathrm{P}$ applied to the soybean. Early P fertilization applied to pasture is technically feasible and can be used to maintain the pasture: it is recommended to replace corrective fertilization for following soybean crops. Key words: Urochloa. Phosphorus availability. Phosphorus accumulation. Residual effect. No-tillage.
\end{abstract}

\section{Resumo}

O objetivo deste trabalho foi avaliar o efeito da adubação fosfatada antecipada aplicada na pastagem de Urochloa decumbens cv. Basilisk sobre a biodisponibilidade de fósforo para a cultura da soja em sucessão à pastagem. A pastagem de baixa produtividade, plantada sobre um Latossolo Vermelho em uma área experimental da Embrapa Cerrados, foi dividida em três piquetes (faixas) de 1,5 ha e adubada anualmente a lanço com 0,20 e $40 \mathrm{~kg} \mathrm{ha}^{-1} \mathrm{de}_{2} \mathrm{O}_{5}$, durante quatro anos. Após a dessecação da pastagem, foi realizada a semeadura da soja e a adubação nas diferentes doses de $\mathrm{P}_{2} \mathrm{O}_{5}$. As doses foram aplicadas em sulco correspondendo à 0,50 e $100 \mathrm{~kg}$ de $\mathrm{P}_{2} \mathrm{O}_{5}$ ha $^{-1}$. $\mathrm{O}$ teor de $\mathrm{P}$ disponível no solo, avaliado durante o cultivo da soja, foi menor com a adubação na pastagem que com a adubação na soja. No entanto, o $P$ residual biodisponível, determinado pelo acúmulo de $\mathrm{P}$ na planta, produção de matéria seca e rendimento de grãos, foi similar quando da aplicação de P na pastagem ou na soja. Assim sendo, a adubação fosfatada antecipada à pastagem é tecnicamente viável, apresentando-se como alternativa para manutenção da pastagem e recomendada para substituir a adubação corretiva na implantação da cultura de soja.

Palavras-chave: Urochloa. Fósforo disponível. Fósforo acumulado. Efeito residual. Plantio direto.

${ }^{1}$ Eng $^{\mathrm{o}} \mathrm{Agr}^{\mathrm{O}}$ Dr., Companhia Nacional de Abastecimento, CONAB, Cuiabá, MT, Brasil. E-mail: diogone@yahoo.com.br

2 Pesquisador Dr., Institut de Recherche pour le Développement, IRD, Montpellier, France. E-mail: thierry.becquer@ird.fr

${ }^{3}$ Pesquisadores, Drs., Empresa Brasileira de Pesquisa Agropecuária, EMBRAPA Cerrados, Planaltina, DF, Brasil. E-mail: robelio. marchao@embrapa.br; lourival.vilela@embrapa.br

${ }^{4}$ Prof. Dr., Departamento de Geociências, Universidade Estadual de Londrina, UEL, Londrina, PR, Brasil. E-mail: vendrame@ uel.br

5 Pesquisador, Dr., EMBRAPA Informação Tecnológica, Brasília, DF, Brasil. E-mail: edemar.corazza@embrapa.br

${ }^{6}$ Prof $^{\mathrm{a}} \mathrm{Dr}^{\mathrm{a}}$, Departamento de Agronomia, UEL, Londrina, PR, Brasil. E-mail: mfatima@uel.br

* Author for correspondence 


\section{Introduction}

The predominance of highly weathered soils with high sorption capacity and low phosphorus (P) availability, associated with a lack of regular $\mathrm{P}$ fertilization, decisively contributes to the decline of pasture productivity in the Cerrado Region over time, contributing to its degradation (BROSSARD; BARCELLOS, 2005; NOVAIS et al., 2007). Phosphorus is the nutrient that most limits the production of plants in acidic soils of the Cerrado (DIAS et al., 2015; VENDRAME et al., 2010). However, corrective fertilization of soils with large amounts of phosphate fertilizers is uneconomic and logistically impractical (KRUSE et al., 2015). Thus improved efficiency in its use by reducing amounts of fertilizer applied to the soil is important for the conservation of natural resources and sustainability of agro-ecosystems (BAVEYE, 2015).

The Cerrado Region contains 54 million hectares of grassland (SANO et al., 2010), where an estimated 50 to $80 \%$ have some degree of degradation (BROSSARD; BARCELOS, 2005). In Brazil, application of fertilizer to pasture represents only $1.6 \%$ of total consumption, which means a negligible amount of $4 \mathrm{~kg} \mathrm{ha}^{-1}$ NPK (SOUSA et al., 2007). In this sense, annual crop and pasture rotation appears to be an alternative to chemical restoration and for maintaining the physical characteristics of soils (VILELA et al., 2011) and the sustainability of agriculture in the Cerrado (MACEDO, 2009).

One of the main benefits of annual crop rotation and pastures is the use, by pasture, of the residual effect of fertilizer applied to cereals (BALBINOT JÚNIOR et al., 2009). Since the crop rotation includes species that are very efficient at extracting $\mathrm{P}$, such as Urochloa, the resulting increased $\mathrm{P}$ recovery adds up to $69 \%$ more to the soil than a system composed only of annual crops (SOUSA et al., 2007). This effect of Urochloa is due to root system morphology: the density of the roots and their association with mycorrhizal fungi increase the $\mathrm{P}$ uptake due to the exploitation of a larger volume of soil and solubilization of organic phosphates by phosphatases produced by the hyphae and the mobilization of inorganic P (CASTRO et al., 2013; JANEGITZ et al., 2013; YAO et al., 2001).

Another strategy is to apply all or part of the annual crop's fertilization to the preceding crop, which is usually a green manure in non-tilled pasture or crop-livestock systems (SOUSA et al., 2007). Francisco et al. (2007) and Rodrigues et al. (2009) reported that early $\mathrm{P}$ fertilization of wiregrass [Eleusine coracana (L.) Gaertn.], produced more plant biomass and an accumulation of $\mathrm{P}$ which did not affect soybean grain yield. Thus, early fertilization of the preceding crop can increase long-term biomass production, improving conservation of soil moisture through an increase in plant residues and improved nutrient cycling and biomass mineralization, releasing nutrients for the next crop (SEGATELLI et al., 2008).

With the increasing adoption of integrated croplivestock farming in Brazil and the use of plants from the genus Urochloa, it is becoming necessary to assess the effect of the cultivation of these plants on the P cycling efficiency and consequent availability of this nutrient for subsequent crops. Hence the objective of this study was to assess the effect of early application of phosphate fertilizer to an Urochloa decumbens pasture on the availability of soil $\mathrm{P}$ and the bioavailability of $\mathrm{P}$ to the soybean following the pasture.

\section{Materials and Methods}

The study was conducted in 2006 in the Embrapa Cerrados experimental area, Planaltina-

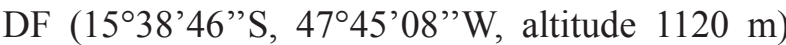
on an Oxisol with the following features: 650, 120 and $230 \mathrm{~g} \mathrm{~kg}^{-1}$ clay, silt and sand, respectively, $\mathrm{pH}$ (water) of $5.21,24.5 \mathrm{~g} \mathrm{~kg}^{-1}$ of total carbon, 2.78, $0.70,0.09,5.43$ and $0.46 \mathrm{cmol}_{\mathrm{c}} \mathrm{kg}^{-1}$ of $\mathrm{Ca}, \mathrm{Mg}, \mathrm{Al}$, $\mathrm{H}+\mathrm{Al}$ and $\mathrm{K}$, respectively; $2.37 \mathrm{mg} \mathrm{kg}^{-1}$ available $\mathrm{P}$ (Mehlich-1). The climate is tropical, seasonal (Aw), according to the Köppen classification, with 
an average annual rainfall of $1,500 \mathrm{~mm}$ and mean maximum and minimum temperatures of 26.4 and $15.9^{\circ} \mathrm{C}$, respectively. Rainfall and mean monthly temperature during the growth of soybeans are shown in Figure 1.

Figure 1. Precipitation and average monthly temperature for the 2006/2007 crop.

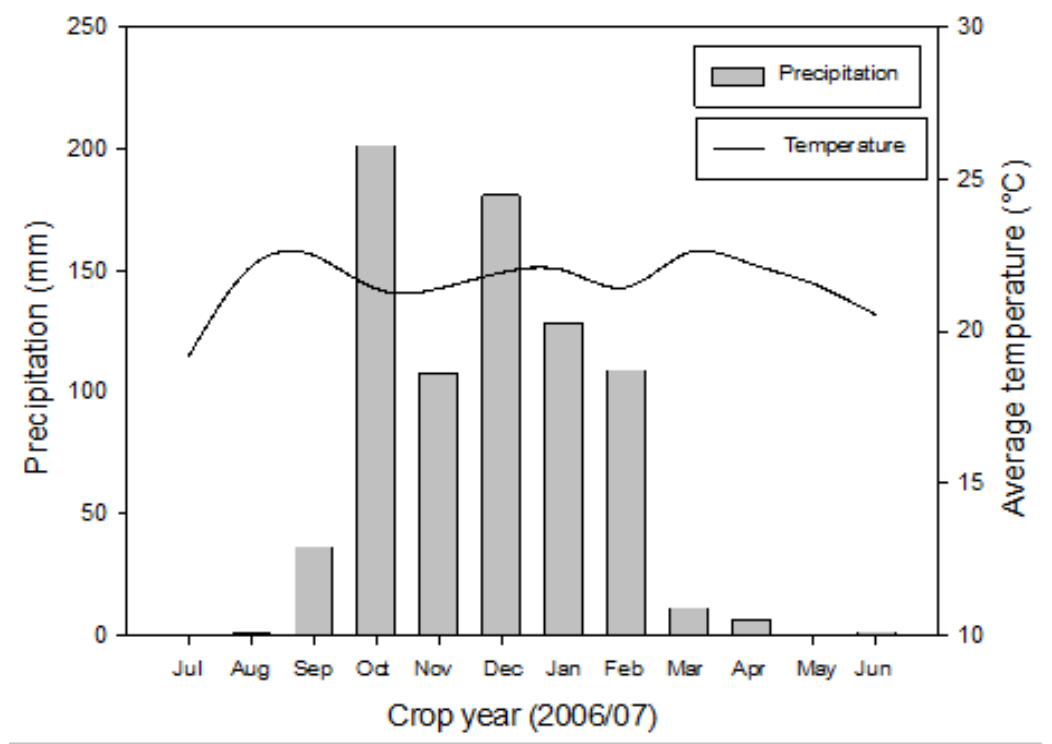

Management of the experimental area began in 1998 when the plot received $1.1 \mathrm{Mg} \mathrm{ha}^{-1}$ of lime incorporated into the soil, $60 \mathrm{~kg} \mathrm{ha}^{-1}$ of $\mathrm{P}_{2} \mathrm{O}_{5}$ in the form of simple superphosphate and $30 \mathrm{~kg}$ ha $^{-1}$ of FTE $^{\circledR}$ BR-10 (Fritted Trace Elements) for micronutrient correction. In 1999, Urochloa decumbens cv. Basilisk was sown and left fallow until 2002. In October of that year, when the pasture was already becoming degraded, the area was divided into three 1.5 hectare plots [175 $\mathrm{m} \mathrm{x} 86 \mathrm{~m}$ ], onto which 0 (P0), 20 (P20) and 40 (P40) kg ha-1 of $\mathrm{P}_{2} \mathrm{O}_{5}$ was broadcast annually, in the form of simple superphosphate, until 2006. During four years, the land was used for grazing. Over the four years, a total of $300 \mathrm{~kg} \mathrm{ha}^{-1}$ of nitrogen was applied in the form of urea $\left(\left(\mathrm{NH}_{2}\right)_{2} \mathrm{CO}\right)$ and $120 \mathrm{~kg} \mathrm{ha}^{-1}$ of $\mathrm{K}_{2} \mathrm{O}$ was applied as $\mathrm{KCl}$, to maintain available soil $\mathrm{K}$ close to $1.3 \mathrm{mmol}_{\mathrm{c}} \mathrm{kg}^{-1}$ (VILELA et al., 2007).

In November 2006, the pasture was desiccated using $1.44 \mathrm{~kg} \mathrm{P} \mathrm{ha}^{-1}$ of glyphosate active ingredient to sow soybean cv. BRS Valiosa RR with no tillage. The treatments were stablished from the perpendicularly phosphorus fertilization (in relation to pasture fertilization) with triple superphosphate at doses of 0 (S0), 50 (S50) and 100 (S100) $\mathrm{kg} \mathrm{ha}^{-1}$ of $\mathrm{P}_{2} \mathrm{O}_{5}$ in a split plot design strip block with four replications. The area of each plot was $58 \mathrm{~m}$ x 86 $\mathrm{m}$ (Table 1). The average soybean plant population in the area, 14 days after emergence (DAE), was 12 per meter of row, with rows spacing of $0.45 \mathrm{~m}$.

Soybean plants (4 subsamples in each plot) were randomly collected, from $1 \mathrm{~m}$ lengths of two crop rows at the full bloom growth stage (R2) (100 $\mathrm{DAE})$. The composite samples were dried at $65^{\circ} \mathrm{C}$ to constant weight and ground for chemical analysis. $\mathrm{P}$ content (P-Plant) was quantified by optical emission spectrometry with inductively coupled argon plasma (ICP-AES) after nitro-perchloric acid digestion (EMBRAPA, 1999). The amount of $\mathrm{P}$ accumulated by soybean (P-cumulative, $\mathrm{kg} \mathrm{P} \mathrm{ha}{ }^{-1}$ ) was calculated 
by multiplying the dry matter (DM) produced per hectare by $\mathrm{P}$ concentration. To measure soybean yield, an area of $10 \mathrm{~m}^{2}$ was sampled with grain moisture corrected to $13 \%$.

Soil samples were collected immediately after soybean sampling in the same places. The subsamples were collected within and between rows, from the $0-10 \mathrm{~cm}$ layer, totaling 12 subsamples per local. The samples were packed in plastic bags and stored in a refrigerator at $10^{\circ} \mathrm{C}$ until soil analysis to maintain the moisture and avoid possible changes in the nature of the P (BARTLETT; JAMES, 1980). Available $P$ in the soil was determined using an anion exchange resin (resin-P) (QUAGGIO; RAIJ, 2001) and Mehlich-1 extractant (Mehlich-P) (EMBRAPA, 1999), and the results were expressed based on the dry weight of the samples. The soil $\mathrm{P}$ was analyzed within ten days after sampling. A non-parametric analysis using the Kruskal-Wallis test $(\alpha=0.05)$ was made after checking the absence of normality of data through Kolmogorov-Smirnov test $(\alpha=0.05)$. Multiple comparisons were made by the Student-Newman-Keuls test (SNK) with $5 \%$ probability level. The Bioestat 4.0 software (AYRES et al., 2005) was used for the statistical analysis.

Table 1. Amount of $\mathrm{P}$ fertilizer $\left(\mathrm{kg} \mathrm{P}_{2} \mathrm{O}_{5} \mathrm{ha}^{-1} \mathrm{yr}^{-1}\right)$ applied to each plot of pasture land in 2003 to 2006 and soybeans in 2006.

\begin{tabular}{lccc}
\hline \multicolumn{1}{c}{$\begin{array}{c}\text { Fertilized } \\
\text { plot }^{(+)}\end{array}$} & $\begin{array}{c}\mathrm{P}_{2} \mathrm{O}_{5}\left(\mathrm{~kg} \mathrm{ha}^{-1}\right) \\
\text { applied on the pasture }\end{array}$ & $\begin{array}{c}\mathrm{P}_{2} \mathrm{O}_{5}\left(\mathrm{~kg} \mathrm{ha}^{-1}\right) \\
\text { applied on soya }\end{array}$ & $\begin{array}{c}\text { Total } \mathrm{P}_{2} \mathrm{O}_{5}\left(\mathrm{~kg} \mathrm{ha}^{-1}\right) \\
\text { applied }\end{array}$ \\
\hline $\mathrm{P} 0+\mathrm{S} 0$ & 0 & 0 & 0 \\
$\mathrm{P} 0+\mathrm{S} 50$ & 0 & 50 & 50 \\
$\mathrm{P} 0+\mathrm{S} 100$ & 0 & 100 & 100 \\
$\mathrm{P} 20+\mathrm{S} 0$ & 20 & 0 & 80 \\
$\mathrm{P} 20+\mathrm{S} 50$ & 20 & 50 & 130 \\
$\mathrm{P} 20+\mathrm{S} 100$ & 20 & 100 & 180 \\
$\mathrm{P} 40+\mathrm{S} 0$ & 40 & 0 & 160 \\
$\mathrm{P} 40+\mathrm{S} 50$ & 40 & 50 & 210 \\
$\mathrm{P} 40+\mathrm{S} 100$ & 40 & 100 & 260 \\
\hline
\end{tabular}

(†) Phosphorus fertilization in pasture ( $\mathrm{P} 0,0 \mathrm{~kg} \mathrm{ha}^{-1} \mathrm{P}_{2} \mathrm{O}_{5}$ year ${ }^{-1}, \mathrm{P} 20,20 \mathrm{~kg} \mathrm{ha}^{-1} \mathrm{P}_{2} \mathrm{O}_{5}$ year ${ }^{-1}, \mathrm{P} 40,40 \mathrm{~kg} \mathrm{ha}^{-1} \mathrm{P}_{2} \mathrm{O}_{5}$ year $\left.{ }^{-1}\right)$ for 2003 to 2006, S, Phosphorus fertilization on soya (S0, $\left.0 \mathrm{~kg} \mathrm{ha}^{-1}, \mathrm{~S} 50,50 \mathrm{~kg} \mathrm{ha}^{-1}, \mathrm{~S} 100,100 \mathrm{~kg} \mathrm{ha}^{-1}\right)$.

\section{Results and Discussion}

Levels of available $\mathrm{P}$ in the $0-10 \mathrm{~cm}$ soil layer extracted by resin and Mehlich-1 in the unfertilized plot $\left(0 \mathrm{~kg} \mathrm{P}_{2} \mathrm{O}_{5} \mathrm{ha}^{-1}\right.$ in pasture and soybean) were 3.10 and $2.25 \mathrm{mg} \mathrm{kg}^{-1}$, respectively (Table 2) and are considered low for growing rainfed annual crops (SOUZA; LOBATO, 2004) and medium for less demanding forage species (VILELA et al., 2004). If we consider the $0-20 \mathrm{~cm}$ layer, the P content would probably be even lower due to the accumulation of $\mathrm{P}$ at the surface and the absence of tillage, and soil $\mathrm{P}$ levels classified as very low and low, respectively, for growing annual crops and less demanding forage. Rossi et al. (1999), Corazza et al. (2003) and
Vendrame et al. (2010) also reported low levels of available $\mathrm{P}$ in soils under unproductive pasture.

The maintenance fertilization of 20 and $40 \mathrm{~kg}$ of $\mathrm{P}_{2} \mathrm{O}_{5} \mathrm{ha}^{-1}$ per year applied to pastures led to an increase in levels of $\mathrm{P}$ in soil (Table 2), now ranging from low to high according to the interpretation of Souza et al. (1987), although the amounts applied are considered relatively low and the soils have a high phosphate adsorption capacity (CHAPUISLARDY et al., 2001). Thus, from the residual effect of phosphorus applied annually in pasture maintenance for four years, the area became able to be used for growing annual crops without the need for corrective $\mathrm{P}$ fertilization. 
Table 2. Levels of available $\mathrm{P}$ in soil extracted by anion exchange resin (resin-P) and Mehlich-1 (Mehlich-P) 100 days after soybean emergence as affected by earlier pasture fertilization and $\mathrm{P}$ applied to the soybean.

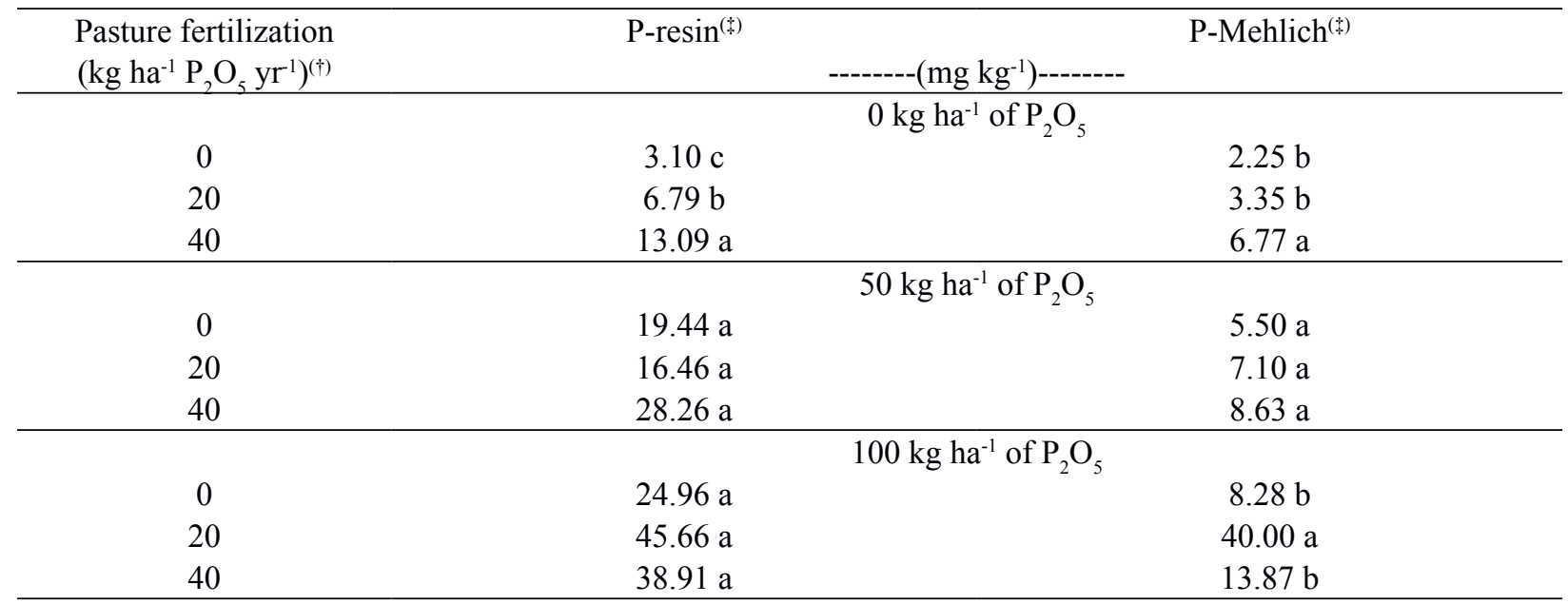

(†)Applied from 2003 to 2006.

(») Means followed by the same letters in column, each of P fertilization in the soybean, do not differ by SNK test at $5 \%$ probability.

P-Mehlich levels were on average 48\% lower than P-resin levels and were positively correlated with them $(r=0.70 ; p<0.01)$. The increased levels of $\mathrm{P}$ obtained with the resin extractant can be related to the fact that the labile reserve of $\mathrm{P}$ occurs mostly as aluminum phosphate (RAIJ, 1978), which restricts extraction by Mehlich-1, due to its acidity (SIMÕES NETO et al., 2009).

Levels of available $\mathrm{P}$ extracted by Mehlich-1 and resin showed a positive correlation $(p<0.01)$ with the shoot dry mass of soybean $(r=0.65$ and 0.72 , respectively). However, the higher correlation coefficient was obtained with resin, indicating that it is the more sensitive method, agreeing with Alcântara et al. (2008) and Freitas et al. (2013). However, some authors have shown that the extractors Mehlich-1 and ion exchange resin were equally effective to assess available soil $\mathrm{P}$ (SCHLINDWEIN et al., 2008).
The available $P$ extracted by resin and Mehlich-1 showed no difference between fertilization levels applied to the pasture on soybean, when the soybean was fertilized (doses of 50 and $100 \mathrm{~kg} \mathrm{ha}^{-1} \mathrm{P}_{2} \mathrm{O}_{5}$ ) (Table 2). However, considering the bioavailability as indicated by related variables (P-Plant, DM, GY and accumulated-P) it appears that there was a residual effect of fertilization on soybean in pasture (Table 3). It appears therefore that the extractants were not sensitive enough to detect residual $\mathrm{P}$ fertilizer in pasture and that the assessment based solely on the results of soil analysis would suggest that only the fertilization applied to the soybean was responsible for the availability of $\mathrm{P}$. This is probably because the extractants used are inefficient to extract organic forms of phosphorus, since the resin and Mehlich-1 reacted mainly on the available inorganic $\mathrm{P}$ in the soil (SANTOS et al., 2008; SOUZA JÚNIOR et al., 2012). 
Table 3. Phosphorus content in shoots, shoot dry mass, grain yield and phosphorus accumulated in shoots at 100 days after emergence of soybeans according to fertilization in pasture in the fertilization in soybean.

\begin{tabular}{|c|c|c|c|c|}
\hline $\begin{array}{c}\text { Fertilization } \\
\text { in pasture } \\
\left(\mathrm{kg} \mathrm{ha}^{-1} \mathrm{P}_{2} \mathrm{O}_{5} \mathrm{yr}^{-1}\right)^{(\dagger)}\end{array}$ & $\begin{array}{c}\text { Phosphorus content } \\
\text { in shoots } \\
\left(\mathrm{g} \mathrm{kg}^{-1}\right) \\
\end{array}$ & $\begin{array}{c}\text { Shoot dry mass }{ }^{(\ddagger)} \\
\left(\mathrm{kg} \mathrm{ha}^{-1}\right)\end{array}$ & $\begin{array}{c}\left.\text { Grain yield }{ }^{\ddagger}\right) \\
\left(\mathrm{kg} \mathrm{ha}^{-1}\right)\end{array}$ & $\begin{array}{c}\text { Phosphorus accumulated } \\
\text { in shoot } \\
\left(\mathrm{kg} \mathrm{ha}^{-1}\right) \\
\end{array}$ \\
\hline & \multicolumn{4}{|c|}{$0 \mathrm{~kg} \mathrm{ha}^{-1}$ of $\mathrm{P}_{2} \mathrm{O}_{5}$} \\
\hline 0 & $1.45 \mathrm{c}$ & $1636 \mathrm{c}$ & $1525 \mathrm{c}$ & $2.37 \mathrm{c}$ \\
\hline 20 & $1.88 \mathrm{~b}$ & $2672 b$ & $2857 \mathrm{~b}$ & $5.05 \mathrm{~b}$ \\
\hline \multirow[t]{2}{*}{40} & $3.06 \mathrm{a}$ & $3586 \mathrm{a}$ & $3647 \mathrm{a}$ & $10.96 \mathrm{a}$ \\
\hline & \multicolumn{4}{|c|}{$50 \mathrm{~kg} \mathrm{ha}^{-1}$ of $\mathrm{P}_{2} \mathrm{O}_{5}$} \\
\hline 0 & $1.72 \mathrm{c}$ & $3222 b$ & $2325 \mathrm{~b}$ & $5.62 \mathrm{~b}$ \\
\hline 20 & $2.45 \mathrm{~b}$ & $3575 \mathrm{~b}$ & 3497 a & $8.75 \mathrm{~b}$ \\
\hline \multirow[t]{2}{*}{40} & $3.02 \mathrm{a}$ & $4781 \mathrm{a}$ & $3905 \mathrm{a}$ & $14.50 \mathrm{a}$ \\
\hline & \multicolumn{4}{|c|}{$100 \mathrm{~kg} \mathrm{ha}^{-1}$ of $\mathrm{P}_{2} \mathrm{O}_{5}$} \\
\hline 0 & $2.31 \mathrm{~b}$ & $3906 \mathrm{~b}$ & $3577 \mathrm{a}$ & $9.03 \mathrm{~b}$ \\
\hline 20 & $2.93 \mathrm{a}$ & 5444 a & $4142 \mathrm{a}$ & $16.00 \mathrm{a}$ \\
\hline 40 & $3.08 \mathrm{a}$ & $4586 \mathrm{ab}$ & $3902 \mathrm{a}$ & $14.16 \mathrm{a}$ \\
\hline
\end{tabular}

(†)Applied from 2003 to 2006 .

(\$) Means followed by the same letters in column, each of P fertilization in the soybean, do not differ by SNK test at $5 \%$ probability.

Soybean DM yields ranged from 1,636 to 5,444 $\mathrm{kg} \mathrm{ha}^{-1}$ (Table 3). With the increase in pasture fertilization, there was an increase in DM yield for all three soybean fertilization levels. The DM yield of soybean also responded positively to the $\mathrm{P}$ applied in 0 and $20 \mathrm{~kg} \mathrm{ha}^{-1}$ of $\mathrm{P}_{2} \mathrm{O}_{5}$ applied in pastures plots. However, on the plot where the pasture had received $40 \mathrm{~kg} \mathrm{ha}^{-1}$ of $\mathrm{P}_{2} \mathrm{O}_{5}$ the $\mathrm{P}$ applied to soybean had no significant effect on its DM yield (Table 3), demonstrating that relatively low annual $\mathrm{P}$ applications to the preceding pasture over four years was as effective as applying P directly to the soybeans. Francisco et al. (2007), who assessed the dry shoot yield of soybean as affected wholly or partly by the residual effect of $\mathrm{P}$ applied to the preceding pasture, also did not observe differences between treatments.

The unfertilized soybean plot $(\mathrm{P} 0+\mathrm{S} 0)$ produced $1,636 \mathrm{~kg} \mathrm{ha}^{-1}$ of DM, 58\% less than the plot fertilized with $100 \mathrm{~kg} \mathrm{ha}^{-1}$ of $\mathrm{P}_{2} \mathrm{O}_{5}$ applied only on the soybean, which produced $3,905 \mathrm{~kg} \mathrm{ha}^{-1}$ of DM. The DM yield in the residually fertilized plot with $160 \mathrm{~kg} \mathrm{ha}^{-1} \mathrm{P}_{2} \mathrm{O}_{5}$ spread over four years in the pasture $(\mathrm{P} 40+\mathrm{S} 0)$ did not differ from the same treatment with $100 \mathrm{~kg}$ $\mathrm{ha}^{-1}$ of $\mathrm{P}_{2} \mathrm{O}_{5}$ applied to the soybean $(\mathrm{P} 40+\mathrm{S} 100)$
(Table 3). These results highlights the importance of aboveground biomass in no tillage rotation systems as seen by Mascarenhas et al. (1981) and Francisco et al. (2007).

Soybean grain yield (GY) ranged from 1,525 to $4,142 \mathrm{~kg} \mathrm{ha}^{-1}$ (Table 3). In the residually fertilized strips from the 0 and $20 \mathrm{~kg} \mathrm{ha}^{-1}$ of $\mathrm{P}_{2} \mathrm{O}_{5}$ on pasture, $\mathrm{GY}$ increased with the increase in soybean fertilization up to the maximum rate. On the other hand, in the $40 \mathrm{~kg} \mathrm{ha}^{-1}$ of $\mathrm{P}_{2} \mathrm{O}_{5}$ residual fertilizer strip, GY was similar for all three directly applied $\mathrm{P}$ rates (S0, S50 and S100). Lana et al. (2003) and Francisco et al. (2007) found similar soybean yields when fertilizer was applied earlier in the same crop year, compared to application at sowing time.

With increasing levels of fertilization, there was also an increase in phosphorus concentration in shoots (P-plant) (Table 3). In all the plots, which received $\mathrm{P}$, either directly or as a residue, P-plant reached levels at least twice as high as on the unfertilized plot. The P40 + S0, P20 + S100, P40 $+\mathrm{S} 50$ and $\mathrm{P} 40+\mathrm{S} 100$ fertilized strips, with the highest levels of $\mathrm{P}_{2} \mathrm{O}_{5}$, had the largest amounts of accumulated $\mathrm{P}$. However, for a three-fold increase in DM yield, 6.7 times accumulated $\mathrm{P}$ was needed 
(Table 2). Ono et al. (2009) reported an increase in $\mathrm{P}$ concentration in soybean, which was greater than the corresponding yield increase. They attributed this to luxury consumption of $\mathrm{P}$.

The accumulated $\mathrm{P}$ in soybean shoot from the residual $\mathrm{P}$ treatments from pasture fertilization (i.e. S0, Table 3) showed a relationship with the P-resin content in the soil (i.e. S0, Table 2), demonstrating that fertilization spread over four years in pasture has a residual effect on the $\mathrm{P}$ accumulation in the shoots and, consequently, on DM production and the grain yield of subsequent crops. On the other hand, after pasture fertilization with $40 \mathrm{~kg}$ of $\mathrm{P}_{2} \mathrm{O}_{5}$ $\mathrm{ha}^{-1}$ applied annually over the previous four years, neither $\mathrm{P}$ accumulation in shoots nor increases in grain yield were observed (Table 3 ).

The levels of phosphorus in soil (P-resin) and phosphorus in the soybean shoots (cumulative-P) for the S50 and S100 levels, showed that the accumulated $\mathrm{P}$ also increased with soil $\mathrm{P}$ availability, than when the soil P levels resulted purely from the fertilization of the pasture. Therefore, high levels of available $\mathrm{P}$ in soil did not result in a higher $\mathrm{P}$ accumulation in the plants when the crop had been directly fertilized with $\mathrm{P}$. This shows that the $\mathrm{P}$ applied to the pasture preceding the soybean and available to the plant is used more efficiently than $\mathrm{P}$ fertilizer applied at soybean sowing. Rossi et al. (1999) evaluated the residual effect of four $\mathrm{P}$ levels and four phosphorus sources applied to two pastures (Centrosema pubescens and Brachiaria decumbens) preceding rice cultivation: they also noted the residual effect of $\mathrm{P}$ coming from triple superphosphate applied to pasture. Considering the role of the root system of grasses in the solubilization of $\mathrm{P}$ by the exudation of organic acids (CORREAA et al., 2004), Urochloa decumbens may have played a key role in the absorption efficiency of residual $\mathrm{P}$ and its subsequent release by mineralization of $\mathrm{P}$ held in DM (organic P). Thus, when the phosphorus is applied - split into four years application to pasture or applied to the soybeans at sowing time - there will be an accumulation of similar amounts of $P$, suggesting that early fertilization on pasture may be an effective strategy to soybean fertilization. These results confirm the hypothesis that long-term grain production is more dependent on the accumulation of soil $\mathrm{P}$ with successive crops than with the management of $\mathrm{P}$ fertilization. This reinforces the need to consider management systems and tillage used when recommended levels of $\mathrm{P}$ in soil are interpreted.

\section{Conclusions}

The residual available $\mathrm{P}$ from the preceding pasture fertilization is more efficiently than $\mathrm{P}$ fertilizer applied at soybean sowing suggesting that early fertilization on pasture may be an effective strategy to soybean fertilization. Phosphate fertilization of soybean through $\mathrm{P}$ applications to the preceding pasture is technically feasible and may be an alternative to recover or maintain pasture productivity as a substitute for direct corrective fertilization in soybean planting.

\section{Acknowledgements}

To Honeywell-SN Centre, BUNGE Fertilizantes $\mathrm{S} / \mathrm{A}$ and the Institut de Recherche pour le Développement (IRD-France) for funding and support for the project. To the soil chemistry laboratory at Embrapa Cerrados and Juaci Vitoria Malaquias from his help with statistical analysis.

\section{References}

ALCÂNTARA, F. A.; FURTINI NETO, A. E.; CURI, N.; RESENDE, A. V. Extraction methods for phosphorus and their relationship with soils phosphorus-buffer capacity estimated by the remaining-phosphorus methodology - a pot study with maize. Communications in Soil Science and Plant Analysis, Philadelphia, v. 39, n. 3-4, p. 603615, 2008. 
AYRES, M. M.; AYRES, J. R.; AYRES, D. L.; SANTOS, A. S. BioEstat 4.0: aplicações estatísticas nas áreas das ciências biológicas e médicas. Belém: Sociedade Civil Mamirauá/MCT-CNPq/Conservation International, 2005. $323 \mathrm{p}$.

BALBINOT JÚNIOR, A. A.; MORAES, A.; VEIGA, M.; PELISSARI, A.; DIECKOW, J. Integração lavourapecuária: intensificação de uso de áreas agrícolas. Ciência Rural, Santa Maria, v. 39, n. 6, p. 1925-1933, 2009.

BARTLETT, R.; JAMES, B. Studying dried, stored soil samples - some pitfalls. Soil Science Society of America Journal, Madison, v. 44, n. 4, p. 721-724, 1980.

BAVEYE, P. C. Looming scarcity of phosphate rock and intensification of soil phosphorus research. Revista Brasileira de Ciência do Solo, Viçosa, MG, v. 39, n. 3, p. 637-642, 2015

BROSSARD, M.; BARCELlOS, A. O. Conversão do Cerrado em pastagens cultivadas e funcionamento de Latossolos. Cadernos de Ciência \& Tecnologia, Brasília, v. 22, n. 2, p. 153-168, 2005.

CASTRO, L. M.; BARBOSA, M. A. A. F.; BARBERO, R. P.; BRITO, V. C.; SAAD, M.; RIBEIRO, E. L. A.; MIZUBUTI, I. Y.; BRIDI, A. M. Produção de forragem e composição estrutural de pastos de Brachiaria brizantha cv. Xaraés manejados em diferentes alturas de pastejo. Semina: Ciências Agrárias, Londrina, v. 34, n. 6, p. 4145-4156, 2013.

CHAPUIS-LARDY, L.; BROSSARD, M.; QUIQUAMPOIX, H. Assessing organic phosphorus status of Cerrado Oxisols (Brazil) using ${ }^{31} \mathrm{P}-\mathrm{NMR}$ spectroscopy and phosphomonoesterase activity measurement. Canadian Journal of Soil Science, Ottawa, v. 81, n. 5, p. 591-601, 2001.

CORAZZA, E. J.; BROSSARD, M.; MURAOKA, T.; COELHO, M. A. Spatial variability of soil phosphorus of a low productivity Brachiaria brizantha pasture. Scientia Agrícola, Piracicaba, v. 60, n. 3, p. 559-564, 2003.

CORRÊA, J. C.; MAUAD, M.; ROSOLEM, C. A. Fósforo no solo e desenvolvimento de soja influenciados pela adubação fosfatada e cobertura vegetal. Pesquisa Agropecuária Brasileira, Brasília, v. 39, n. 12, p. 12311237, 2004

DIAS, K. G. L.; FURTINI NETO, A. E.; GUIMARÃES, P. T. G.; REIS, T. H. P.; OLIVEIRA, C. H. C. Coffee yield and phosphate nutrition provided to plants by various phosphorus sources and levels. Ciência e Agrotecnologia, Lavras, v. 39, n. 2, p. 110-120, 2015.

EMPRESA BRASILEIRA DE PESQUISA AGROPECUÁRIA - EMBRAPA. Manual de análises químicas de solos, plantas e fertilizantes. Rio de Janeiro:
EMBRAPA, 1999. 372 p. (EMBRAPA Solos - Centro Nacional de Pesquisa de Solos).

FRANCISCO, E. A. B.; CÂMARA, G. M. S.; SEGATELLI, C. R. Estado nutricional e produção do capim-pé-de-galinha e da soja cultivada em sucessão em sistema antecipado de adubação. Bragantia, Campinas, v. 66, n. 2 , p. $259-266,2007$.

FREITAS, I. F.; NOVAIS, R. F.; VILLANI, E. M. A.; NOVAIS, S. V. Phosphorus extracted by ion exchange resins and Mehlich-1 from Oxisols (Latosols) treated with different phosphorus rates and sources for varied soil-source contact periods. Revista Brasileira de Ciência do Solo, Viçosa, MG, v. 37, n. 3, p. 667-677, 2013.

JANEGITZ, M. C.; INOUE, B. S.; ROSOLEM, C. A. Soil phosphorus pools as affected by brachiaria and white lupin. Ciência Rural, Santa Maria, v. 43, n. 8, p. 1381-1386, 2013.

KRUSE, J.; ABRAHAM, M.; AMELUNG, W.; BAUM, C.; BOL, R.; KÜHN, O.; LEWANDOWSKI, H.; NIEDERBERGER, J.; OELMANN, Y.; RÜGER, C.; SANTNER, J.; SIEBERS, M.; SIEBERS, N.; SPOHN, M.; VESTERGREN, J.; VOGTS, A.; LEINWEBER, P. Innovative methods in soil phosphorus research: a review. Journal of Plant Nutrition and Soil Science, Weinheim, v. 178, n. 1, p. 43-88, 2015.

LANA, R. M. Q.; VILELA FILHO, C. E.; ZANÃO JÚNIOR, L. A.; PEREIRA, H. S.; LANA, A. M. Q. Adubação superficial com fósforo e potássio para a soja em diferentes épocas em pré-semeadura na instalação do sistema de plantio direto. Scientia Agrícola, Piracicaba, v. 4, n. 1, p. 53-60, 2003.

MACEDO, M. C. M. Integração lavoura e pecuária: o estado da arte e inovações tecnológicas. Revista Brasileira de Zootecnia, Viçosa, MG, v. 38, n. 1, p. 133146, 2009.

MASCARENHAS, H. A. A.; BATAGLIA, O. C.; IGUE, T.; TISSELLI FILHO, O.; MIRANDA, M. A. C.; FERREIRA FILHO, A. W. P. Efeito residual de adubação na produção da soja. Campinas: IAC, 1981. 18 p. (Boletim técnico, 24).

NOVAIS, R. F.; SMYTH, T. J.; NUNES, F. N. Fósforo. In: NOVAIS, R. F.; ALVAREZ, V. V. H.; BARROS, N. F.; FONTES, R. L. F.; CANTARUTTI, R. B.; NEVES, J. C. L. Fertilidade do solo. Viçosa, MG: Sociedade Brasileira de Ciência do Solo, 2007. p. 276-374.

ONO, F. B.; MONTAGNA, J.; NOVELINO, J. O.; SERAFIM, M. E.; DALLASTA, D. C.; GARBIATE, M. V. Eficiência agronômica de superfosfato triplo e fosfato natural de Arad em cultivos sucessivos de soja e milho. Ciência e Agrotecnologia, Lavras, v. 33, n. 3, p. 727-734, 2009. 
QUAGGIO, J. A.; RAIJ, B. Determinação de fósforo, cálcio, magnésio e potássio extraídos com resina trocadora de íons. In: RAIJ, B.; ANDRADE, J. C.; CANTARELla, H.; QUAGGIO, J. A. (Ed.). Análises químicas para avaliação da fertilidade de solos tropicais. Campinas: Instituto Agronômico de Campinas, 2001. p. 189-199.

RAIJ, B. van. Seleção de métodos de laboratório para avaliar a disponibilidade de fósforo em solos. Revista Brasileira de Ciência do Solo, Campinas, v. 2, n. 1, p. 1-9, 1978.

RODRIGUES, C. R.; FAQUIN, V.; ÁVILA, F. W.; RODRIGUES, T. M.; BALIZA, D. P.; OLIVEIRA, E. A. B. Crescimento e acúmulo de fósforo pela soja cultivada em sucessão a diferentes gramíneas forrageiras adubadas com superfosfato triplo e fosfato reativo de Arad. Ciência e Agrotecnologia, Lavras, v. 33, n. 6, p. 1486-1494, 2009.

ROSSI, C.; ANJOS, A. R. M.; CAMAGYO, M. S.; WEBER, O. L. S.; IMHOFF, S.; MALAVOLTA, E. Efeito residual de fertilizantes fosfatados para o arroz: avaliação do fósforo na planta e no solo por diferentes extratores. Scientia Agrícola, Piracicaba, v. 56, n. 1, p. 39-46, 1999.

SANO, E. E.; ROSA, R.; BRITO, J. L. S.; FERREIRA, L. G. Land cover mapping of the tropical savanna region in Brazil. Environmental Monitoring and Assessment, Berlin, v. 166, n. 1-4, p. 113-124, 2010.

SANTOS, D. R.; GATIBONI, L. C.; KAMINSKI, J. Fatores que afetam a disponibilidade do fósforo e o manejo da adubação fosfatada em solos sob sistema plantio direto. Ciência Rural, Santa Maria, v. 38, n. 2, p. 576-586, 2008.

SCHLINDWEIN, J. A.; GIANELlO, C. Nível de suficiência e índice de equivalência entre o fósforo determinado pelos métodos da resina de troca iônica e Mehlich-1. Current Agricultural Science and Technology, Pelotas, v. 14, n. 2, p. 299-306, 2008.

SEGATELLI, C. R.; CÂMARA, G. M. S.; HEIFFIG, L. S.; FRANCISCO, E. A. B.; ÁGUILA, J. S.; PIEDADE, S. M. S. Producción de materia seca de mijo africano (Eleusine coracana (L.) Gaertn.) sobre sistema de abono anticipado de soya. Interciencia, Caracas, v. 33, n. 7, p. 542-546, 2008.

SIMÕES NETO, D. E.; OLIVEIRA, A. C.; FREIRE, F. J.; FREIRE, M. B. G. S.; NASCIMENTO, C. W. A.; ROCHA, A. T. Extração de fósforo em solos cultivados com cana-de açúcar e suas relações com a capacidade tampão. Revista Brasileira de Engenharia Agrícola e Ambiental, Campina Grande, v. 13, n. 6, p. 840-848, 2009.
SOUSA, D. M. G.; MARTHA JÚNIOR, G. B.; VILELA, L. Adubação fosfatada. In: MARTHA JÚNIOR, G. B.; VILELA, L.; SOUSA, D. M. G. (Ed.). Cerrado: uso eficiente de corretivos e fertilizantes em pastagens. Planaltina: EMBRAPA Cerrados, 2007. p. 145-178.

SOUZA JÚNIOR, R. F.; OLIVEIRA, F. H. T.; SANTOS, H. C.; FREIRE, F. J.; ARRUDA, J. A. Frações de fósforo inorgânico do solo e suas correlações com o fósforo quantificado por extratores e pelo milho. Revista Brasileira de Ciência do Solo, Viçosa, MG, v. 36, n. 1, p. 159-169, 2012.

SOUZA, D. M. G.; LOBATO, E. Cerrado: correção do solo e adubação. Brasília: EMBRAPA, 2004. 416 p. (EMBRAPA Informação Tecnológica).

SOUZA, D. M. G.; MIRANDA, L. N.; LOBATO, E. Interpretação de análises de terra e recomendação de adubos fosfatados para culturas anuais nos Cerrados. Planaltina: EMBRAPA Cerrados, 1987. 7 p. (Embrapa Cerrados. Comunicado técnico, 51).

VENDRAME, P. R. S.; BRITO, O. R.; GUIMARÃES, M. F.; MARTINS, E. S.; BECQUER T. Fertility and acidity status of Latosols (oxisols) under pasture in the Brazilian Cerrado. Anais da Academia Brasileira de Ciências, Rio de Janeiro, v. 82, n. 4, p. 1085-1094, 2010.

VILELA, L.; MARTHA JÚNIOR, G. B.; MACEDO, M. C. M.; MARCHÃO, R. L.; GUIMARÃES JÚNIOR, R.; PULROLNIK, K.; MACIEL, G. A. Sistemas de integração lavoura-pecuária na região do Cerrado. Pesquisa Agropecuária Brasileira, Brasília, v. 46, n. 10, p. 1127-1138, 2011.

VILELA, L.; MARTHA JÚNIOR, G. B.; BARIONI, L. G.; BARCELLOS, A. O. Adubação na recuperação e na intensificação da produção animal em pastagens. In: SIMPÓSIO SOBRE O MANEJO DA PASTAGEM, FERTILIDADE DO SOLO PARA PASTAGENS PRODUTIVAS, 21., 2004, Piracicaba. Anais... Piracicaba: FEALQ, 2004. p. 425-472.

VILELA, L.; MARTHA JÚNIOR, G. B.; SOUSA, D. M. G. Adubação potássica e com micronutrientes. In: MARTHA JÚNIOR, G. B.; VILELA, L.; SOUSA, D. M. G. (Ed.). Cerrado: uso eficiente de corretivos e fertilizantes em pastagens. Planaltina: EMBRAPA Cerrados, 2007. p. 179-187.

YAO, Q.; LI, X.; FENG, G.; CHRISTIE, P. Mobilization of sparingly soluble phosphates by the external mycelium of an arbuscular mycorrhizal fungus. Plant and Soil, Berlin, v. 230, n. 2, p. 279-285, 2001. 
